supplies to support the scientific program beginning in 1961 . The party consisted of the following: S. Apollonio, leader; V. D. Boyd, master mechanic; B. D. Clarke, tractor specialist; C. R. Harington, naturalist and general assistant; G. R. Lowther, archaeologist; R. S. McCall, archaeological assistant; D. R. Oliver, zoologist and general assistant; G. E. Stewart, Weasel specialist.

The party left Quebec City on July 31 on board C.M.S. d'Iberville and arrived off Cape Skogn, Devon Island on August 20. By August 24 a camp consisting of three prefabricated Jamesway buildings and stores for twenty people for 5 months was installed at $75^{\circ} 42^{\prime} \mathrm{N}$. $84^{\circ} 26^{\prime} \mathrm{W}$.

An 18-mile tractor route to the edge of the ice cap was then laid out and 6 tons of ice cap station supplies were hauled to the top of a 1000-foot plateau at the beginning of that route. The top of the plateau, the only practicable route to the ice cap, was found to be thawed to such an extent that the tractors became mired to the axles. It was decided to cache the supplies at the edge of the plateau and to establish the ice cap station in the spring of 1961, when the ground will be frozen.

On September 6, Apollonio, Harington, and Stewart examined the ice cap margin and found that it is readily accessible to tracked vehicles. The base camp, the power boat, the two diesel tractors, and the two Weasels were then secured for the winter.

The party were picked up by helicopter of the U.S. icebreaker Westwind and taken to Thule, Greenland, from where they flew on a USAF MATS flight to New Jersey and returned to Montreal on September 16.

The archaeologists located two previously unknown sites. The first, in the vicinity of the base camp, includes four or five houses, three temporary houses, and several caches. It is probably a late Thule site.

The second site is located near the western tip of Cape Sparbo and has been tentatively named the "Inapok" site. It was studied by Lowther, McCall, and Oliver from August 26 to August
31 and includes 9 houses, tent rings, and a number of other structures. There are undoubtedly both Dorset and Thule, and perhaps pre-Dorset elements in the site. The entire site is well preserved and has yielded about 90 artifacts including Dorset blades, microblade points, burins, microburins, burin spalls, knives, and end blades.

Oliver continued his study of arctic chironomids and other aquatic insects by extensive collecting at Resolute and on Devon Island. Harington measured over 60 musk ox skulls and made a comprehensive plant collection.

The Devon Island Station will be reoccupied in late April 1961, at which time the ice cap station will be established. Studies in meteorology, glaciology, oceanography, marine biology, and geology will then begin. The archaeological work will continue with a detailed excavation of the "Inapok" site and further reconnaissance of the island.

\section{Spencer Apollonio}

\section{Ellesmere Island Ice Shelf Project 1960}

During 1960 the Arctic Institute of North America continued the studies in Ellesmere Island that were begun in 1959 under contract to the Terrestrial Sciences Laboratory of Air Force Cambridge Research Center of the U.S. Air Force. The Defence Research Board of Canada had an observer with the party, and the Institute cooperated in the field with groups from Dartmouth College, Hanover, N.H. and the U.S. Naval Civil Engineering Laboratory. Twenty-three persons were actively engaged in field work between April 26 and September 24,1960 , but only seven men remained on the Ice Shelf throughout the season - Dr. Lister, R. B. Sagar, R. L. Lenton, F. Layman, J. Mulholm, I. Spokas, and R. Grant. Dr. G. Rigsby was in charge of the overall program for the Institute, and Dr. H. F. Lister was the Field Leader. Personnel and supplies were airlifted by a turbo jet C130 Hercules under the command of Captain G. Khourie.

The main program was an evaluation of the mass balance of the Ward Hunt Ice Shelf and Ice Rise. A survey line from the mainland to the edge of the Ice 
Shelf, established in 1959 was resurveyed. $R$. W. Mason and his team installed a grid of markers for an aerial survey, but unfortunately the Royal Canadian Air Force Air Photography Wing was unable to make the necessary flights on account of poor weather conditions. General climatic observations and detailed micrometeorological studies were made on the Ice Shelf and Ice Rise by Lister and Sagar. In addition, level lines were run across the Ice Shelf, a 30-day tidal record was kept at the Shelf edge, and ablation/accumulation measurements made over a grid of 70 stakes. R. Ragle of Dartmouth College directed the coring of some deep holes in the ice of both the Ice Shelf and the Ice Rise at four locations. The cores obtained were flown out to Dartmouth College for fabric analysis. A detailed geomorphological study of the coast of Ellesmere Island opposite Ward Hunt Island and of Ward Hunt Island was made by Dr. J. Lyons. The N.C.E.L. party under D. E. Well conducted studies of the ice surface with special attention to factors affecting suitability for aircraft landings.

Although few quantitative results of the work are available as yet, snow accurnulation was found to be more than 50 per cent greater than in a comparable period in 1959. The summer of 1960 was relatively warm, but the net loss of the ice by melting and run-off only equalled that of 1959 . There is some indication that the radiation regime of the area controls the amount of summer melt. The results of ice core analysis and the geomorphological studies may help to throw some light on the history of the Ice Shelf, and the combined studies are intended to evaluate the critical conditions that govern the growth and breakup of shelf ice in the region.

R. B. SAgar

\section{Missing field party on Great Bear Lake}

Miss Annemarie Kröger and Miss Joan Goodfellow were reported missing during July while working on Smith Arm of Great Bear Lake. They had been making a geomorphological study of the region with special attention to the raised beaches of the area and the glacial history. It was the second season on the lake for Kröger and the work this year was jointly sponsored by the Arctic Institute of North America and the Geographical Branch of the Department of Mines and Technical Surveys, Canada.

Alarm was raised when a pilot of Mackenzie Airways failed to contact the women when flying-in supplies to a prearranged cache. On July 18 the Royal Canadian Mounted Police in a chartered aircraft discovered their overturned canoe with outboard motor and two life jackets in Good Hope Bay. R.C.M.P. aircraft then searched both shores of Smith Arm, and in nearly 80 hours of flying a quantity of jerry-cans and camping gear was recovered, together with a note left by the pair at their last main camp on July 8. There was no trace of the missing women.

A ground party was landed by the salvaged canoe on the morning of July 29 and the entire northern shore was examined on foot or from the canoe, with the hope of discovering traces of survivors from an accident. Although this search led to the discovery of more minor debris it did not reveal any traces of the party west of their last established camp, and from all the evidence it would seem that both women drowned when their canoe upset near the mouth of the Katseyedie River. The ground search was discontinued on the night of August 6, but R.C.M.P. aircraft frequently searched Smith Arm until freeze-up without results.

Annemarie Kröger was a Canadian citizen working as a Research Associate at McGill University, Montreal, but came originally from Hamburg, Germany. Joan Goodfellow was from Plaster Rock, New Brunswick, and was to have joined the Geographical Branch after the expedition.

\section{Gifts to the Library}

The Institute Library acknowledges with thanks gifts of books and reprints from the following persons and organizations:

T. J. Cade

F. A. Cook 